\author{
Yu. Sotnikova, E. StePANOVA, N. NAZAROV
}

\title{
MASS LAYOFF MANAGEMENT AT DOMESTIC ENTERPRISES
}

The subject of the study is to analyze the behaviour of employees in the context of personnel reduction taking into account the current transformational conditions of the business environment of Ukrainian enterprises. The goal of the study is to identify the ways to overcome the problem of mass layoffs considering the peculiarities of the domestic labour market development. The objective is to set up a commission to facilitate the process of reemployment of laid-off employees and specify its place in resolving labour disputes and conflicts within the National Mediation and Reconciliation Service (NMRS); to determine the main stages for implementing the strategy of employee layoffs focusing on suggested measures and the areas of responsibility of authorized people; to create a pattern for the relationship among employees who need assistance and those institutions that carry it out. While dealing with the problem such common scientific methods are used as the system, graphical and structural analysis. The following results are obtained: the expediency of implementing the strategy of behaviour of the subjects of social and labor relations in the case of employee layoffs is justified; under the conditions of transformations, due attention should be paid to the development of a strategy for employee layoffs so that the whole procedure is carried out in accordance with European requirements and standards; the structure of the commission which is in charge for decisions on the issues of reemployment is presented; the sequence of stages for implementing the strategy of behaviour of subjects of social and labour relations in the event of employee layoffs is developed. Conclusions. The implementation of the rapid response strategy will make the process of employee laying off the most comfortable for all participants: redundant personnel will get psychological support; the local community will reduce the rate of unemployment in the region.

Keywords: strategy, mass layoffs, the employment assistance commission, the unemployed, the parties of social dialogue.

\section{Problem statement}

The process of laying off is always difficult for a wide range of participants - for those who are going to be laid off, for those who are going to continue working, for employers and for a local community. That is why the advanced foreign experience for solving the task of mass layoffs is reasonable to be used at Ukrainian enterprises.

The issue of personnel layoffs occurs, as a rule, when a company needs to either reduce or redesign its activities. Personnel layoffs lead to the reduction of the excessive number of employees, to the elimination of noncompliance with the requirements employees should meet, to the reduction of additional costs due to low productivity and quality. Therefore, it is an economic necessity.

\section{Recent studies and publications}

The issues of mass layoffs and their impact on the local community are not sufficiently studied by Ukrainian scientists. Such foreign scientists as S. Appelbaum, M. Bailey, K. Cameron, D. Colvin, F. Hayek, W. McKinley, V. Zibert and others have studied the issues of mass layoffs and the ways to overcome this problem.

\section{Unsolved issues of the general problem. The goal of the paper}

The issues of mass layoffs are currently studied only as a matter of law and psychological constituent is not taken into consideration. Therefore, this paper focuses on the fact that employees who are going to be laid off need psychological support as well as the ways of economic and organizational cooperation of all stakeholders who are engaged in the laying off process.

The goal of the study is to determine the ways for overcoming the problem of mass layoffs taking into consideration the peculiarities of the domestic labour market development.
The objectives of the study are:

- to set a commission to facilitate the reemployment of laid-off employees and specify its place in resolving labour disputes and conflicts within the National Mediation and Reconciliation Service (NMRS);

- to determine the main stages for implementing the strategy of employee layoffs focusing on suggested measures and the areas of responsibility of authorized people;

- to create a pattern for the relationship among employees who need assistance and those institutions that carry it out.

\section{Materials and methods}

The basic materials used while writing this paper are the domestic laws and regulations which deal with personnel laying off (in particular, the Code of Laws on Labour, The Law of Ukraine "On the Employment of Population") as well as the works of leading foreign scientists who have focused on the issues of mass layoffs. The methods of the study include the method of theoretical generalization, system analysis and scientific classification, graphical method for visualizing the received materials, the comparative method.

\section{The results of the study}

The study of the institutional environment of mass employee layoffs and responsible parties enables determining the strategy of the behaviour of the subjects of social and labour relations in the event of mass employee layoffs as an activity implemented by the employment assistance commission in the event of closing down enterprises, institutions or organizations or mass layoffs and aimed at assisting laid-off employees in obtaining necessary services and employment in the shortest possible time [6].

Personnel layoffs are activities that involve a 
number of measures to comply with legal norms and organizational and psychological support from the administration when the employees of an enterprise are laid off.

Personnel layoffs require:

- that the labour laws should be met;

- that the selection criteria should be clear and maximally objective;

- that costs should be minimized and expenses should be cut down;

- that further expenses and expenses linked with layoffs should be prevented;

- publicity;

- working place matching;

- information;

- compensation and assistance in reemployment.

When any layoffs are probable, their consequences should be avoided or maximally mitigated using all available opportunities for this. In a critical situation, when the staff cannot be restructured painlessly by increasing staff mobility, retraining new professions, creating new jobs, the staff have to be reduced. This measure is forced and negative in the social aspect (for example, in Japan for a long time the policy of the longlife employment was proclaimed according to national traditions).

West companies organize mass layoffs only in extreme cases (moreover, it is connected with the great resistance of trade unions), they prefer a flexible employment policy.

The analysis of the foreign experience of implementing such a strategy enables concluding that the Employment Assistance Commission (EAC) should be created. The main purpose of such a commission is introducing the strategy of mass layoffs which will include [2]:

- representatives of employees;

- representatives of employers;

- local executive bodies acting by a representative of the local employment service;

- a specialist on restructuring;

- representatives of the vocational training centre and professional orientation centre.

The Employment Assistance Commission for laidoff employees is an indicative associative body that is suggested to be created in the event of mass layoffs by one or several enterprises in the region and that is aimed at reducing the load on the regional labour market by employing laid-off employees before they become unemployed.

According to foreign experience, in the first stage, the government through legislative mechanisms issues permits for the strategy for managing mass layoffs and establishes the Employment Assistance Commission. For example, the first experimental strategies of rapid response on mass layoffs with the use of EAS took place in the United States in the early 1980s and were so successful that in 1988 the US Congress adopted the law that considered EAC as the main method for minimizing negative impacts of mass layoffs for employees and communities. In each state, national assistance departments were created to help employees who faced the probability of laying off [4].

The insurance funds of the unified social tax which are transferred to centralized accounts of funds of the mandatory state unemployment insurance are suggested as a source of funding for the strategy. The fund resources are used to promote employment at the local and state levels, namely:

- at the state level - to create and develop centres for training and teaching laid-off employees, to carry out scientific researches and developments on the problems of population employment; to maintain information and computer centres, enterprises of employment service; to conduct international activity and cooperation in the sphere of employment;

- at the local level - to carry out professional guidance, retraining and redirection of laid-off employees and the unemployed; to provide compensatory payments to the unemployed who are registered in employment centres; to ensure financial assistance to the unemployed and their family members and so on.

Since the Unemployment Insurance Fund is targeted at the measures aimed at training and teaching laid-off employees, these resources can be directed at implementing the mass layoff management strategy. Apart from the Fund resources, in order to provide financial support for the strategy of the mass layoff management, the EAC parties agree on the amount and distribution of financial resources assigned to the EAC parties (including enterprises that lay off employees) and to the state that acts through the State Employment Service and the Department of Social Protection of the Population. Some agreements also specify other types of support (e.g. equipment, premises, staff) that the employer, employer representatives and the state provide for the EAC.

Let us detail on each member of the EAC and those functions which they should fulfil [5].

Employer representatives or trade unions control of the compliance the rights of laid-off employees, identify the needs for training laid-off employees and provide feedback to the enterprise employees.

Employer representatives provide information on the volumes of planned employee layoffs to the state employment service and ensure the implementation of all measures of the rapid response strategy by providing material and informational support.

Local executive authorities acting through the representatives of the State Employment Service (SES) and the Department of Social Protection of the Population provide the network of early warning network that will accumulate accurate and up-to-date information on the state of regional enterprises in order to identify those enterprises that are going to lay off employees or are planning to close down and also regularly monitor these enterprises in order to determine the term of interaction with them and the time when the strategy of mass layoffs management will start.

The feasibility of implementing the strategy of mass layoffs management is caused by the fact that one of the tasks of the State Employment Service in accordance with the new law "On the Employment of Population" is the 
implementation of programs aimed at preventing the mass employee layoffs. The management strategy can become an effective trend for this task.

The representatives of the Interdepartmental Commission on Regional Development provide information on the state of social and economic development of regions, their problematic issues and also provide material support for the implementation of the strategy.

Representatives of the Centre of the professional training organization together with the local education authorities and the representatives of employees develop measures on the interaction with the organization of vocational training of laid-off employees, along with educational authorities determine the network of educational establishments, enterprises, organizations and institutions of all forms of ownership that will be the basis for training laid-off employees and create the appropriate data bank.

Experience shows that for the efficient strategy of mass layoffs management and large-scale measures for providing assistance to employees who have been laid-off due to the reduction of personnel and enterprise closing down, a qualified specialist on restructuring should be engaged in the strategy [7].

The stages of the strategy implementation are presented in Table 1. The strategy is implemented within 23 - 33 days, depending on the scale and complexity of employee layoffs in one or another enterprise. As a result of the strategy implementation, a certain number of employees who are going to be laid off will be employed or prepared to find a new job before the two-month notice period of the scheduled layoff is over.

Table 1. The stages of the mass layoffs strategy

\begin{tabular}{|c|c|c|}
\hline $\begin{array}{l}\text { Stage and } \\
\text { term }\end{array}$ & $\begin{array}{l}\text { The measures implemented } \\
\text { within the stage }\end{array}$ & People responsible for the implementation of the measures \\
\hline $\begin{array}{l}\text { Stage } 1 \\
\text { (48 hours) }\end{array}$ & $\begin{array}{l}\text { 1.1. Organizing the network for timely warning } \\
\text { about laying off; } \\
\text { 1.2. Assessing the state of enterprises in the } \\
\text { context of laying off; } \\
\text { 1.3. Organizing the connection with a specialist on } \\
\text { restructuring }\end{array}$ & $\begin{array}{l}\text { State employment service (SES); } \\
\text { employer representatives; } \\
\text { a specialist in restructuring }\end{array}$ \\
\hline $\begin{array}{l}\text { Stage } 2 \\
(2-4 \text { days })\end{array}$ & $\begin{array}{l}\text { 2.1. Meeting with the employer to discuss the } \\
\text { layoff of employees or the enterprise closing down }\end{array}$ & $\begin{array}{l}\text { a specialist in restructuring; } \\
\text { employer representatives; } \\
\text { employee representatives }\end{array}$ \\
\hline $\begin{array}{l}\text { Stage } 3 \\
(2-3 \text { days })\end{array}$ & $\begin{array}{l}\text { 3.1. Preliminary assessment of volumes and } \\
\text { severity of probable layoffs }\end{array}$ & $\begin{array}{l}\text { a specialist of restructuring on the basis of SES } \\
\text { information, the department of social protection of the } \\
\text { population, the regional development commission }\end{array}$ \\
\hline $\begin{array}{l}\text { Stage } 4 \\
\text { (5-7 days) }\end{array}$ & $\begin{array}{l}\text { 4.1. Holding a seminar on laying off; } \\
\text { 4.2. Organizing the information and methodical } \\
\text { centre of supporting laid-off employees }\end{array}$ & $\begin{array}{l}\text { a specialist in restructuring; } \\
\text { employer representatives; } \\
\text { employee representatives }\end{array}$ \\
\hline $\begin{array}{l}\text { Stage } 5 \\
\text { (10-14 days) }\end{array}$ & $\begin{array}{l}\text { 5.1. The organization and implementation of the } \\
\text { program for the assistance and secondary } \\
\text { employment of laid-off employees }\end{array}$ & $\begin{array}{l}\text { a specialist in restructuring; employer representatives; } \\
\text { employee representatives; SES, professional training } \\
\text { centre }\end{array}$ \\
\hline $\begin{array}{l}\text { Stage } 6 \\
(2-3 \text { days })\end{array}$ & $\begin{array}{l}\text { 6.1. Assessing the efficiency of selected methods of } \\
\text { working with the employees who have been laid off }\end{array}$ & $\begin{array}{l}\text { a specialist in restructuring on the basis of SES } \\
\text { information, employer representatives; } \\
\text { employee representatives }\end{array}$ \\
\hline
\end{tabular}

This will reduce the number of unemployed who enter the labour market after laying off as well as will ensure more efficient use of labour potential by redistributing laid off employees among the regional enterprises. The period of being unemployed is directly related to the probability of finding a job that in the future may turn into a problem of long-term unemployment $[6,10]$. Unemployed who are registered in employment centres for 1-3 months hope for psychological support a little more often than those who are engaged in this system for a long time - $20 \%$ (up to 3 months) and $15 \%$ (over a year). The need for almost all services offered by the SES decreases when the length of being registered increases.

From a practical point of view, the most difficult is the 5th stage of the strategy. At this stage, on the basis of the information received by the information and methodological centre of assistance, all employees who need help are organized into functional groups according to the kind of assistance they need from the EAC [8-9].

State strategic planning will greatly help to avoid the reduction of personnel, for example, as a result of an appropriate labour force recruitment policy and marketoriented skilled workforce. If this fails, the strategic planning involves compensatory measures in accordance with the reserve of time such as stimulating voluntary exit in order to avoid more severe layoff measures.

\section{Conclusions and further development prospects}

Involving the representatives of the executive and employment services in the mass layoff procedure will, firstly, enable obtaining the necessary material and informational assistance, and secondly, solving a set of 
problems of laid-off employees partially before they receive the status of the unemployed, which, in turn, in accordance with the foreign experience, will reduce the unemployment rate in the region.

The phased implementation of the identified problem will enable preparing the necessary public bodies involved in the mass layoff procedure, simplifying the process of the layoff procedure management for the employer and identifying the functional groups of employees who need help and enable structuring the areas of work with them.

The necessity to create the Employment Assistance Commission as an indicative associative body by one or several enterprises in the region that carry out mass employee layoffs, which is codified by law in the event of mass layoffs can be considered as one of the main trends of further development of the mentioned problem.

\section{References}

1. Economic activity of the population of Ukraine in 2017 [Ekonomichna aktyvnist' naselennya Ukrayiny u 2017 rotsi], Derzhkomstat Ukrayiny, Kyyiv: Derzhanalitinform, 2017, 205 p.

2. Nazarova, G. V., Nazarov, N. K. (2017), "The analysis of structural configurations for implementing competitive strategies" ["Analiz strukturnykh konfiguratsiy dlya realizatsii konkurentnykh strategiy"], Innovative Technologies and Scientific Solutions for Industries, No. 2 (2), P. 132-137. DOI: https://doi.org/10.30837/2522-9818.2017.2.132.

3. Karpenko, O. A. (2001), Economic mechanism of the labor market formation: authors' thesis [Ekonomichnyy mekhanizm formuvannya rynku pratsi:] avtoref. dys. na zdobuttya nauk. stupenya kand. ekon. nauk, Kyiv, 16 p.

4. Staut, L. U. [Upravleniye personalom: nastol'naya kniga menedzhera], Moskva, Dobraya kniga, 2007, 536 p.

5. "Statistical information. The State Statistics Committee of Ukraine", available at: www.ukrstat.gov.ua (last accessed: 14.05.2018)

6. Krayevs'ka, V. O. (2010), Theoretical, legal and practical aspects of the release of employees and their subsequent employment: authors' thesis [Teoretyko-pravovi ta praktychni aspekty vyvil'nennya pratsivnykiv ta yikh podal'shoyi zaynyatosti] avtoref. dys. na zdobuttya nauk. stupenya kand. yuryd. nauk. Luhans'k, 20 p.

7. Sotnikova, Yu. V. (2013), "Development of organizational and economic mechanism for regulating the release of employees". Municipal economy of cities: scientific and technical collection [Rozrobka orhanizatsiyno-ekonomichnoho mekhanizmu rehulyuvannya vyvil'nennya naymanykh pratsivnykiv, Komunal'ne hospodarstvo mist: naukovo-tekhnichnyy zbirnyk], Kharkiv, KHNMAH, No. 108, P. 486-492.

8. Stepanova, E. R., Nazarov, N. K., Sotnikova, Yu. V. (2015), Quality of working life as the strategic direction of domestic enterprises' activity, Economic Journal - XXI: Scientific Specialty Magazine, No. 7-8 (1), P. 106-108.

9. Honcharova, S. Yu., Sotnikova, Yu.V. (2015), Release of hired workers: regional peculiarities: monograph [Vyvilnennya naymanykh pratsivnykiv: rehional'ni osoblyvosti: monohrafiya], Kharkiv : KHNEU im. S. Kuznetsya, 164 p.

10. Nazarova, H. V., Kasmin, D. S. (2016), Ensuring the development of the youth labor market on the basis of monitoring. Scientific herald of Uzhgorod University [Zabezpechennya rozvytku rynku pratsi molodi na zasadakh monitorynhu, Naukovyy visnyk Uzhhorodskoho universytetu], Uzhhorod: DVNZ "UzhNU", No. 1 (47), Vol. 2, P. 30-34.

Receive 07.06.2018

\section{Відомості про авторів / Сведения об авторах / About the Authors}

Сотнікова Юлія Володимирівна - кандидат економічних наук, Харківський національний економічний університет імені Семена Кузнеця, доцент кафедри економіки та соціальних наук, м. Харків, Україна; e-mail: sotnikova_yuliia@i.ua; ORCID: 0000-0001-9058-7746.

Сотникова Юлия Владимировна - кандидат экономических наук, Харьковский национальный экономический университет имени Семена Кузнеца, доцент кафедры экономики и социальных наук, г. Харьков, Украина; e-mail: sotnikova_yuliia@i.ua; ORCID: 0000-0001-9058-7746.

Sotnikova Yulia - PhD (Economics Sciences), Simon Kuznets Kharkiv National University of Economics, Associate Professor at the Department of Economics and Social Sciences, Kharkiv, Ukraine; e-mail: sotnikova_yuliia@i.ua; ORCID: 0000-0001-9058-7746.

Степанова Ека Рамінівна - кандидат економічних наук, Харківський національний економічний університет імені Семена Кузнеця, доцент кафедри економіки та соціальних наук, м. Харків, Україна; e-mail: eka.stepanova@ukr.net; ORCID: 0000-0002-3101-5876.

Степанова Эка Раминивна - кандидат экономических наук, Харьковский национальный экономический университет имени Семена Кузнеца, доцент кафедры экономики и социальных наук, г. Харьков, Украина; e-mail: eka.stepanova@ukr.net; ORCID: 0000-0002-3101-5876.

Stepanova Eka - PhD (Economics Sciences), Simon Kuznets Kharkiv National University of Economics, Associate Professor at the Department of Economics and Social Sciences, Kharkiv, Ukraine; e-mail: eka.stepanova@ukr.net; ORCID: 0000-0002-3101-5876.

Назаров Нікіта Костянтинович - кандидат економічних наук, Харківський національний економічний університет імені Семена Кузнеця, доцент кафедри менеджменту та бізнесу, м. Харків, Україна; e-mail: nikita_nazarov_88@ukr.net; ORCID: 0000-0001-8760-2248.

Назаров Никита Константинович - кандидат экономических наук, Харьковский национальный экономический университет имени Семена Кузнеца, доцент кафедры менеджмента и бизнеса, г. Харьков, Украина; e-mail: nikita_nazarov_88@ukr.net; ORCID: 0000-0001-8760-2248. 
Nazarov Nikita - PhD (Economics Sciences), Simon Kuznets Kharkiv National University of Economics, Associate Professor at the Department of Management and Business, Kharkiv, Ukraine; e-mail: nikita_nazarov_88@ukr.net; ORCID: 0000-0001-8760-2248.

\section{УПРАВЛІННЯ МАСОВИМ ВИВІЛЬНЕННЯМ ПРАЦІВНИКІВ НА ВІТЧИЗНЯНИХ ПІДПРИЕМСТВАХ}

Предметом дослідження в статті $є$ процеси аналізу поведінки працівників у випадку вивільнення 3 урахуванням сучасних трансформаційних умов господарювання українських підприємств. Метою дослідження є визначення шляхів подолання проблеми масового вивільнення працівників з урахуванням особливостей розвитку вітчизняного ринку праці. Завдання: навести склад комісії по сприянню вторинному працевлаштуванню вивільнених працівників та визначити іiі місце в структурі вирішення трудових спорів та конфліктів в рамках діяльності Національної служби посередництва та примирення (НСПП); визначити основні етапи реалізації стратегії масового вивільнення працівників із зазначенням заходів, що пропонуються та сфери відповідальності уповноважених осіб; побудувати схему взаємозв'язку між працівниками, які потребують допомоги та тими інститутами, які іiі здійснюють. Використовуються загальнонаукові методи: системний аналіз, графічний, структурний аналіз. Отримано такі результати: обгрунтовано доцільність впровадження стратегії поведінки суб'єктів соціально-трудових відносин у разі масового вивільнення працівників. В умовах трансформаційних перетворень слід приділяти належну увагу саме побудові стратегії вивільнення персоналу, щоб вся процедура була виконана згідно 3 європейськими вимогами та стандартами. Наведено структуру комісії, якій делеговано вирішення питань щодо вторинного працевлаштування. Побудовано каскад етапів реалізації стратегії поведінки суб'єктів соціально-трудових відносин у випадку масового вивільнення. Висновки. Впровадження стратегії швидкого реагування дозволить зробити процес масового вивільнення найбільш комфортним для всіх учасників: для працівників, що вивільняються - шляхом психологічної підтримки; для місцевого співтовариства - скоротити рівень безробіття в регіоні.

Ключові слова: стратегія, масове вивільнення, Комісія по сприянню вторинного працевлаштування, безробітні, сторони соціального діалогу.

\section{УПРАВЛЕНИЕ МАССОВЫМ УВОЛЬНЕНИЕМ РАБОТНИКОВ НА ОТЕЧЕСТВЕННЫХ ПРЕДПРИЯТИЯХ}

Предметом исследования в статье являются процессы анализа поведения работников в случае высвобождения с учетом современных трансформационных условиях хозяйствования украинских предприятий. Целью исследования является определение путей решения проблемы массового высвобождения работников с учетом особенностей развития отечественного рынка труда. Задача: привести состав комиссии по содействию вторичном трудоустройству высвобожденных работников и определить ее место в структуре разрешения трудовых споров и конфликтов в рамках деятельности Национальной службы посредничества и примирения (НСПП); определить основные этапы реализации стратегии массового высвобождения работников с указанием мер, предлагаемых и сферы ответственности уполномоченных лиц; построить схему взаимосвязи между работниками, нуждающихся в помощи и теми институтами, которые ее осуществляют. Используются общенаучные методы: системный анализ, графический, структурный анализ. Получены следующие результаты: обоснована целесообразность внедрения стратегии поведения субъектов социально-трудовых отношений в случае массового высвобождения работников. В условиях трансформационных преобразований следует уделять должное внимание именно построению стратегии высвобождения персонала, чтобы вся процедура была выполнена в соответствии с европейскими требованиями и стандартами. Приведена структура комиссии, которой делегированы решение относительно вторичного трудоустройства. Построен каскад этапов реализации стратегии поведения субъектов социально-трудовых отношений в случае массового высвобождения. Выводы. Внедрение стратегии быстрого реагирования позволит сделать процесс массового высвобождения наиболее комфортным для всех участников: для высвобождаемых работников - путем психологической поддержки; для местного сообщества - сократить уровень безработицы в регионе.

Ключевые слова: стратегия, массовое высвобождение, Комиссия по содействию вторичного трудоустройства, безработные, стороны социального диалога. 